\title{
Influence of Salicylic Acid on Ion Distribution, Enzymatic Activity and Some Agromorphological Characteristics of Wheat under Salt-affected Soil
}

\author{
E.M. Hafez ${ }^{\#}$ \\ Department of Agronomy, Faculty of Agriculture, Kafrelsheikh \\ University, Kafrelsheikh, Egypt.
}

\begin{abstract}
A
FIELD experiment carried out to examine the effects of soil salinity on morphological and physiological characters of two wheat cultivars differing in salt tolerance and the modulation of ion distribution and activities of antioxidant enzyme by exogenous application of salicylic acid under salt-affected soil. The experiment was designed in split plot design. Two wheat cultivars including Sakha93 (salt-tolerant) and Gemmiza9 (salt-sensitive) were assigned in main plots. Three levels of salicylic acid including $(0,100$ and 200 $\mathrm{mg} \mathrm{L}^{-1}$ ) were allocated to the subplots in 2013/2014 and 2014/2015 seasons. Salt-tolerant cultivar (Sakha93) showed higher morphological and physiological characters than salt sensitive one (Gemmiza9). Exogenous application of salicylic acid maintained lower $\mathrm{Na}^{+}$concentration with higher $\mathrm{K}^{+} / \mathrm{Na}^{+}$ratio in flag leaf blade in Sakha93 as compared to Gemmiza9. Exogenous application of salicylic acid increased $\mathrm{K}^{+}$and decreased $\mathrm{Na}^{+}$in Gemmiza9 as compared to untreated plants. Side by side, the improvement of ion distribution might be due to increment in activities of antioxidant enzymes catalase (CAT) and peroxidase (POX) by exogenous higher salicylic acid level $\left(200 \mathrm{mg} \mathrm{L}^{-1}\right)$ in 2013/2014 and 2014/2015 seasons. It could be concluded that exogenous application of $200 \mathrm{mg} \mathrm{SA} \mathrm{L}^{-1}$ has effective impact in increasing yield-traits and grain yield under salt-affected soil condition.
\end{abstract}

Keywords: Wheat, Salicylic acid, $\mathrm{K}^{+} / \mathrm{Na}^{+}$, Catalase, Peroxidase

Wheat (Triticum aestivum L.) is one of the most outstanding cereal food which owing a central role in world's food security. It is the fundamental food crop for more than one-fifth of human populace around the globe especially in Egypt (FAO, 2014). By the end of year 2050, it is predicted that the global population will grow to reach about 10 billion. Otherwise, wheat productivity is reducing due to the impact of different abiotic stresses which lead to loss millions of dollars annually. Therefore, it is important to minimize these losses to face the increasing food requirements (Maswada \& Abd El-Kader, 2016).

In arid and semi-arid areas of the world such as Egypt is suffering from abiotic stresses. Abiotic stresses such as salinity is a global issue which adversely "For Correspondence: emadhafez2014@gmail.com 
affects crop growth and decrease productivity, constraining physiological and biochemical processes in plants and ion imbalance (Munns \& Tester, 2008 and Hafez \& Abou El-Hassan, 2015). Munns \& Tester (2008) stated that more than 45 million hectares of irrigated land have been damaged by salt worldwide and roughly 1.5 million hectares are taken out of production each year due to high salinity levels in the soil. Thus, it is worthy to enhance the performance of crop plants, especially food crops, under saline condition. In Egypt, approximately $33 \%$ of the cultivated land is salt-affected due to low rainfall $(<25 \mathrm{mM}$ annual rainfall) and saline water irrigation (Ghassemi et al., 1995).The efficient choice to diminish the deleterious impacts of salinity on productivity is the selection of salt-resistant cultivars (Hafez \& Abdelaal, 2015 and Zhu et al., 2016).

Salt-affected soils lead to uptake higher rates of $\mathrm{Na}$ and exclude $\mathrm{K}$ in plants (Zhang et al., 2010), resulting in poor $\mathrm{K}^{+} / \mathrm{Na}^{+}$discrimination under salt stress (Shabala \& Munns, 2012) which reduce yield-related traits and ultimately grain yield (Hafez et al., 2015 and Zhu et al., 2016). In addition to promote scavenging of reactive oxygen species (ROS) (Amjad et al., 2014). Low concentrations of $\mathrm{Na}^{+}$in the leaves of wheat are linked to salt tolerance (Munns \& Tester, 2008). Therefore, it has been demonstrated that minimize $\mathrm{Na}^{+}$uptake in plants is considered to be one of the substantial mechanisms to reduce the harmful effects of salt stress (Zhang et al., 2010). Hence, alleviate detrimental impacts of salt stress on crops has received considerable attention.

Recently, many strategies are being practiced in the world to cope with salt stress; exogenous application of natural and safety substances is the one that is getting considerable attention, which regulate various physiological and biochemical processes in plants and enhance yield productivity (Rahnama et al., 2011). Salicylic acid (SA) is one of safety substances which having ability of antioxidant defense system and has a major role in counteracting of abiotic stress such as salinity in wheat (Shakirova et al., 2003). Exogenous application of salicylic acid alleviates deleterious impact of salt-induced owing to its ability in stomatal regulation and ion uptake in wheat (Arfan et al., 2007 and Hafez et al., 2014).

Although a lot of agricultural researches have been done on the response of wheat to salt stress. However, relatively little information is available regarding role of exogenous application by salicylic acid on growth, yield performance, ion balance and biochemical characters under salt-affected soil conditions in wheat cultivars which is also imperative to study. In addition, the mechanisms of this regulation under stress have not been fully elucidated yet. Thus, the present research was undertaken to explore the role of exogenous application by salicylic acid in amelioration of adverse effects of soil salinity. Furthermore, study ions distribution in leaf blade in two 'bread wheat cultivars differing in salt tolerance and the activity of antioxidative enzymes.

Egypt. J. Agron. 38, No.3 (2016) 


\section{Material and Methods}

\section{Plant material and experimental site}

Two wheat (Triticum aestivum L.) cultivars, Sakha-93 as salt-tolerant and Gemmiza-9 as salt sensitive, were selected based on the previous researches of (El-Lethy et al., 2013). The tested cultivars were obtained from the Wheat Research Department, Field Crops Research Institute, Egypt. The Experiment was carried out at Water Requirements Research Station (El-Karada), Water Management Research Institute, National Water Research Centre, Kafrelsheikh Governorate (North Delta, Latitude: $31^{\circ} 6^{\prime} \mathrm{N} /$ Longitude: $30^{\circ} 56^{\prime} \mathrm{E}$ ), Egypt, during the winter growing seasons of 2013/2014 and 2014/2015. Meteorological data at El-Karada Station during two growing seasons (2013/2014 and 2014/2015) are presented in Table 1. Before seedbed preparation, the experimental soil was ploughed twice and randomized three soil samples ( 0 to 30 $\mathrm{cm}$ depth) were taken for analysis, physical and chemical properties in the experimental soil are shown in Table 2.

TABLE 1. Meteorological data for El-Karada Station during growing seasons.

\begin{tabular}{|c|c|c|c|c|c|c|c|c|}
\hline \multirow{3}{*}{ Month Year } & \multicolumn{4}{|c|}{$2013 / 2014$} & \multicolumn{4}{|c|}{$2014 / 2015$} \\
\hline & \multicolumn{2}{|c|}{$\begin{array}{c}\text { Temperature } \\
\text { (C) }\end{array}$} & \multirow{2}{*}{$\begin{array}{c}\text { Precipitation } \\
(\mathbf{m m})\end{array}$} & \multirow{2}{*}{$\begin{array}{l}\text { RH } \\
(\%)\end{array}$} & \multicolumn{2}{|c|}{$\begin{array}{c}\text { Temperature } \\
\text { (C) }\end{array}$} & \multirow{2}{*}{$\begin{array}{c}\text { Precipitation } \\
(\mathbf{m m})\end{array}$} & \multirow{2}{*}{$\begin{array}{l}\text { RH } \\
(\%)\end{array}$} \\
\hline & $\max$ & $\min$ & & & $\max$ & $\min$ & & \\
\hline Dec & 26.9 & 11.4 & 0.80 & 30.7 & 24.9 & 10.9 & 0.60 & 32.6 \\
\hline Jan & 23.5 & 9.4 & 3.50 & 41.4 & 22.2 & 9.7 & 3.30 & 43.1 \\
\hline Feb & 22.0 & 11.0 & 7.00 & 45.1 & 20.8 & 12.7 & 7.60 & 44.2 \\
\hline Mar & 24.0 & 16.2 & 0.00 & 47.9 & 22.5 & 14.7 & 0.50 & 45.4 \\
\hline April & 27.4 & 17.2 & 0.00 & 55.4 & 25.7 & 16.1 & 0.00 & 53.1 \\
\hline May & 31.9 & 17.8 & 0.00 & 64.1 & 30.3 & 15.4 & 0.00 & 65.8 \\
\hline
\end{tabular}

$\max =$ maximum, $\min =$ minimum, $\mathrm{RH}=$ relative humidity

TABLE 2. Chemical properties of soil used in 2013/2014 and 2014/2015 growing seasons.

\begin{tabular}{|c|c|c|c|c|c|c|c|c|c|}
\hline \multirow{2}{*}{ Year } & \multirow{2}{*}{$\begin{array}{c}\text { EC } \\
\left(\mathbf{d s ~ m}^{-\mathbf{1}}\right)\end{array}$} & \multicolumn{4}{|c|}{ Cations $\left(\mathbf{m e q} \mathbf{L}^{-\mathbf{1}}\right)$} & \multicolumn{3}{c|}{ Anions $\left(\mathbf{m e q} \mathbf{L}^{-\mathbf{1}}\right)$} \\
\cline { 3 - 11 } & $\mathbf{p H}$ & $\mathbf{N a}^{+}$ & $\mathbf{K}^{+}$ & $\mathbf{M g}^{++}$ & $\mathbf{C a}^{++}$ & $\mathbf{C l}^{-}$ & $\mathbf{H C o}_{\mathbf{3}}{ }^{-}$ & $\mathbf{S o}_{\mathbf{4}}^{-{ }^{-}}$ \\
\hline $2013 / 2014$ & 3.04 & 8.05 & 12.78 & 0.73 & 4.76 & 6.54 & 13.56 & 4.22 & 1.54 \\
\hline $2014 / 2015$ & 2.89 & 7.98 & 10.65 & 0.86 & 5.23 & 7.29 & 13.21 & 3.67 & 1.98 \\
\hline
\end{tabular}

Soil analysis for $\mathrm{pH}$ based on soil: water extract (1: 2.5$)$, while EC and ions based on soil: water extract (1:5). Soil texture was clayey.

\section{Experimental design and treatments}

The experiment was designed in a randomized complete block design (RCBD) of a split plot arrangement with three replicates. Two wheat cultivars including (Sakha 93 and Gemmiza 9) were assigned in main plots. Three levels of salicylic acid including $\left(0,100\right.$ and $\left.200 \mathrm{mg} \mathrm{L}^{-1}\right)$ were allocated to the subplots. 
Salicylic acid (SA) had foliar sprayed twice using hand atomizer and wetting agent at 30 and 60 days after sowing (DAS). The preceding crop was Maize (Zea mays L.) during the growing seasons. Calcium superphosphate $\left(15.5 \% \mathrm{P}_{2} \mathrm{O}_{5}\right)$ was added at the rate of $250 \mathrm{~kg} \mathrm{ha}^{-1}$ during seedbed preparation, $\mathrm{N}$ fertilizer was applied at rate of $170 \mathrm{~kg} \mathrm{~N} \mathrm{ha}^{-1}$ as ammonium nitrate $(33.5 \% \mathrm{~N})$ to each plot at three splits; $20 \%$ as basal dose at sowing stage, $40 \%$ at jointing stage and the remaining $40 \%$ at booting stage.

The experiment was planted on November $20^{\text {th }}$ during 2014/2015 and November $28^{\text {th }}$ during $2015 / 2016$ with row spacing of $15 \mathrm{~cm}$ by drilling machine and a seeding rate $125 \mathrm{~kg} \mathrm{ha}^{-1}$. Weeds were controlled by Topik $15 \%$ WP herbicide. The net experimental unit size (plot) was $10.5 \mathrm{~m}^{2}$ ( 3 m width $\times 3.5$ $\mathrm{m}$ long). Wheat grain yield obtained by harvesting the center $(2 \mathrm{~m} \mathrm{x} 2 \mathrm{~m})$ of the experimental unit, but yield components were determined from two outer rows within each plot. Plots were separated by $0.5 \mathrm{~m}$ allays.

\section{Morphological and physiological measurements}

Flag leaf area $\left(\mathrm{cm}^{2}\right)$ measurement

Ten flag leaves from each plot were collected at heading stage, when the flag leaf was fully expanded to measure flag leaf area by Leaf Area Meter (Li-Cor 3100, Lambda Instruments Co., USA).

\section{Chlorophyll content (SPAD)}

At heading stage, chlorophyll content was measured by portable chlorophyll meter (SPAD-502; Minolta Sensing Co., Ltd, Japan) at three different positions of fully expanded leaves (Markwell et al., 1995) to measure leaf greenness of the plants.

Analysis of sodium and potassium ion concentrations

At heading stage, oven- dried samples of leaves from each plot in oven at 70 ${ }^{\circ} \mathrm{C}$ for $48 \mathrm{~h}$. Fine ground leaves $(0.5 \mathrm{~g})$ into fine powder were digested with concentrated $\mathrm{H}_{2} \mathrm{SO}_{4}(5 \mathrm{ml})$ and $80 \%$ perchloric acid $(1 \mathrm{ml})$. Digested material diluted by distilled deionized water brought up to $100 \mathrm{ml}$ final volume. The concentrations of $\mathrm{Na}^{+}$and $\mathrm{K}^{+}$were determined using PFP7 Flame photometer (Temminghoff \& Houba, 2004).

$$
\mathrm{K} / \mathrm{Na}=(\% \mathrm{~K} \text { in leaf }) /(\% \mathrm{Na} \text { in leaf })
$$

\section{Leaf relative water content}

Leaf relative water content is a useful measure of the physiological water status of plants under salt- affected soil (Gonzalez \& Gonzalez-Vilar, 2001). At heading stage, leaves detached from the stem were weighted to determine fresh weight (FW). Turgid weight (TW) was estimated after the leaves were kept floating in distilled water into a closed petri dish at $10^{\circ} \mathrm{C}$ in the dark for $24 \mathrm{~h}$ and weighted again. Dry weight (DW) was determined for leaves samples after ovendrying for $72 \mathrm{~h}$ at $80^{\circ} \mathrm{C}$. RWC was calculated using the following equation: LRWC $(\%)=[(\mathrm{FW}-\mathrm{DW}) /(\mathrm{TW}-\mathrm{DW})] \times 100($ Jeon et al., 2006) .

Egypt. J. Agron. 38, No.3 (2016) 


\section{Extraction and assay of antioxidant enzymes}

For the determination of antioxidant enzyme activities in wheat leaves at heading stage, $0.5 \mathrm{~g}$ leaf material was homogenized at $0-4^{\circ} \mathrm{C}$ in $3 \mathrm{ml}$ of $50 \mathrm{mM}$ TRIS buffer (pH 7.8), containing $1 \mathrm{mM}$ EDTA-Na ${ }^{2}$ and $7.5 \%$ polyvinyl pyrrolidone. The homogenates were centrifuged $\left(12,000 \mathrm{rpm}, 20 \mathrm{~min}, 4^{\circ} \mathrm{C}\right)$, and the total soluble enzyme activities were determined spectrophotometrically in the supernatant (Hafez et al., 2012). All measurements were undertaken at $25^{\circ} \mathrm{C}$, using the model UV-160A spectrophotometer (Shimadzu, Japan).The enzyme assays were tested three times. Activity of catalase (CAT) was measured spectrophotometrically based on Aebi (1984). Differences in the absorbance at $240 \mathrm{~nm}$ were measured every $30 \mathrm{sec}$ intervals for $3 \mathrm{~min}$. Enzyme activity was expressed as the increase in absorbance $\min ^{-1} \mathrm{~g}^{-1}$ fresh weight. The method used for extraction and determination of peroxidase (POX) activity was extracted as described by Hammerschmidt et al. (1982). Differences in absorbance at $470 \mathrm{~nm}$ were measured every $30 \mathrm{sec}$ intervals for $3 \mathrm{~min}$. Enzyme activity was expressed as the increase in absorbance $\min ^{-1} \mathrm{~g}^{-1}$ fresh weight.

Yield and related traits

Total number of spikes $\mathrm{m}^{-2}$ from each plot were carefully counted and averaged to determine number of spikes $\mathrm{m}^{-2}$. Length of ten random selected spikes was taken from each experimental unit and averaged to measure spike length. Total number of spikelet's spike ${ }^{-1}$ and number of grains spike ${ }^{-1}$ from ten randomly selected spikes were counted carefully and averaged to record number of spikelet's and grains per spike. Five random samples each of 1000 grains were taken, weighed and averaged to measure 1000-grain weight. At harvest maturity, each plot was harvested manually, sun dried for three days and tied into bundles. These bundles were then threshed manually and grains were separated and weighed to record grain yield (14\% moisture content). Left over straw was again weighed to record straw yield. Grain and straw yields were converted into $\mathrm{kg} \mathrm{ha}^{-1}$. Harvest index (HI) was determined as ratio between grain and biological yield and was expressed in percentage.

\section{Statistical analysis}

Data obtained were subjected to an analysis of variance (ANOVA) procedures according to Gomez \& Gomez (1984) using the MSTAT-C Statistical Software package. Different Means were compared using (Duncan, 1955), when the ANOVA showed significant differences $(\mathrm{P}<0.05)$.

\section{Results and Discussion}

Effect of treatments on flag leaf area, chlorophyll content and relative water content under salt-affected soil

Salt stress diminished flag leaf area, chlorophyll content and leaf relative water content of both cultivars; Sakha93 (salt-tolerant cultivar) and Gemmiza9 (salt-sensitive cultivar). However, exogenous application of salicylic acid has a positive impact in improving growth traits including, flag leaf area, chlorophyll 
content and relative water content of the two wheat cultivars compared to control under salt-affected soil (Table 3).

TABLE 3. Effect of cultivars and salicylic acid levels on (flag leaf area, chlorophyll content and relative water content, respectively) in 2013/2014 and 2014/2015 seasons.

\begin{tabular}{|l|c|c|c|c|c|c|}
\hline \multirow{2}{*}{ Treatments } & \multicolumn{2}{|c|}{$\begin{array}{c}\text { Flag leaf area } \\
\left(\mathbf{c m}^{\mathbf{2}}\right)\end{array}$} & \multicolumn{2}{c|}{$\begin{array}{c}\text { Chlorophyll } \\
\text { content (SPAD) }\end{array}$} & \multicolumn{2}{c|}{$\begin{array}{c}\text { Relative water } \\
\text { content }\end{array}$} \\
\cline { 2 - 7 } & $\mathbf{2 0 1 3})$ & $\mathbf{2 0 1 4}$ & $\mathbf{2 0 1 3}$ & $\mathbf{2 0 1 4}$ & $\mathbf{2 0 1 3}$ & $\mathbf{2 0 1 4}$ \\
\hline $\begin{array}{l}\text { Cultivars (C) } \\
\text { Sakha93 }\end{array}$ & $39.45 \mathrm{a}$ & $40.25 \mathrm{a}$ & $48.95 \mathrm{a}$ & $49.75 \mathrm{a}$ & $94.52 \mathrm{a}$ & $95.47 \mathrm{a}$ \\
\hline Gemmiza9 & $33.57 \mathrm{~b}$ & $34.45 \mathrm{~b}$ & $43.37 \mathrm{~b}$ & $44.23 \mathrm{~b}$ & $91.64 \mathrm{~b}$ & $91.45 \mathrm{~b}$ \\
\hline Salicylic acid levels (SA) $\left(\mathrm{mg} \mathrm{L}^{-1}\right)$ & \multicolumn{5}{|l}{} \\
\hline 0 & $32.78 \mathrm{c}$ & $33.24 \mathrm{c}$ & $42.88 \mathrm{c}$ & $43.37 \mathrm{c}$ & $90.54 \mathrm{~b}$ & $91.23 \mathrm{c}$ \\
\hline 100 & $35.25 \mathrm{~b}$ & $36.46 \mathrm{~b}$ & $46.54 \mathrm{~b}$ & $47.32 \mathrm{~b}$ & $93.45 \mathrm{a}$ & $93.78 \mathrm{~b}$ \\
\hline 200 & $37.95 \mathrm{a}$ & $38.85 \mathrm{a}$ & $48.87 \mathrm{a}$ & $49.45 \mathrm{a}$ & $93.87 \mathrm{a}$ & $94.56 \mathrm{a}$ \\
\hline C $\times$ SA & $\mathrm{ns}$ & $\mathrm{ns}$ & $\mathrm{ns}$ & $\mathrm{ns}$ & $\mathrm{ns}$ & $\mathrm{ns}$ \\
\hline
\end{tabular}

Data within columns followed by different letters are significantly different at $\mathrm{P}<0.05$; ns, no significant difference.

Sakha93 significantly recorded maximum flag leaf area (39.45 and 40.25 $\mathrm{cm}^{2}$ ), chlorophyll content (48.95 and 49.75) and relative water content (94.52 and $95.47 \%$ ) in both seasons, respectively compared with Gemmiza9 which recorded minimum flag leaf area $\left(33.57\right.$ and $34.45 \mathrm{~cm}^{2}$ ), chlorophyll content (43.37 and 44.23) and relative water content (91.64 and 91.45\%) in both seasons, respectively (Table 3). In the line of the results (Hafez \& Kobata, 2012 and Maswada \& Abd El-Kader, 2016) demonstrated that Sakha94 as salt tolerance with higher growth traits under salt stress and Gemmiza9 as saltsensitive with higher reduction in growth traits under salt stress. Rana et al. (2015) reported that salt-tolerance cultivars were higher growth traits may be because of higher water uptake under salt stress as compared to salt-sensitive cultivars. Singh et al. (2015) also reported that a salt tolerant cultivar had lower accumulation of salts in the leaves may be due to higher antioxidant activity, as compared to a salt-sensitive cultivar that uptake harmful ions leading to turgor loss.

Exogenous application of salicylic acid remarkedly increased flag leaf area, total chlorophyll content and relative water content in both seasons (Table 3). Salicylic acid enhanced flag leaf area, chlorophyll content and leaf chlorophyll content in both seasons which indicate that salicylic acid assuaged the detrimental impacts of salinity. These results are in agreement with previous studies that reported that salicylic acid application enhanced plant growth, flag leaf area, chlorophyll content and relative water content under salt-affected soils (Sakhabutdinova et al., 2003 and Hafez \& Gharib, 2016). The highest flag leaf Egypt. J. Agron. 38, No.3 (2016) 
area (37.95 and $38.85 \mathrm{~cm}^{2}$ ), chlorophyll content (48.87 and 49.45) and relative water content ( 93.87 and $94.56 \%)$ were recorded by exogenous application (200 $\mathrm{mg} \mathrm{L}^{-1} \mathrm{SA}$ ) compared to control treatment (without application SA) which recorded The lowest flag leaf area $\left(32.78\right.$ and $\left.33.24 \mathrm{~cm}^{2}\right)$, chlorophyll content (42.88 and 43.37) and relative water content (90.54 and 91.23\%) in both seasons, respectively. It might be attributed to the external supply of salicylic acid on physiological processes, such as the growth regulation and promotion, metabolism and differentiation of cells under salt-affected soil and increment nutrients and water absorption (Manzoor et al., 2015). Manzoor et al. (2015) showed that salt stress was mitigated by exogenous application of salicylic acid, which observed that salicylic acid led to decline transpiration and stomata opening and increase relative water content.

Effect of treatments on 1000-grain weight, number of grains spike ${ }^{-1}$ and number of spikes $m^{-2}$

Wheat grain yield is a result of shared factors of some yield-related traits, i.e. 1000 -grain weight, number of grains spike ${ }^{-1}$ and number of spikes $\mathrm{m}^{-2}$. Salt stress reduced the yield due to marked reduction in traits relevant to yield (Table 4).

TABLE 4. Effect of cultivars andsalicylic acid levels on (1000-grain weight, number of grains spike ${ }^{-1}$ and number of spikes $\mathrm{m}^{-2}$, respectively) in 2013/2014 and 2014/2015 seasons.

\begin{tabular}{|l|c|c|c|c|c|c|}
\hline \multirow{2}{*}{ Treatments } & \multicolumn{2}{|c|}{$\begin{array}{c}\text { 1000-grain } \\
\text { weight }(\mathbf{g})\end{array}$} & \multicolumn{2}{c|}{$\begin{array}{c}\text { Number of grains } \\
\text { spike }^{-1}\end{array}$} & \multicolumn{2}{c|}{$\begin{array}{c}\text { Number of spikes } \\
\text { m }^{-2}\end{array}$} \\
\cline { 2 - 7 } & $\mathbf{2 0 1 3}$ & $\mathbf{2 0 1 4}$ & $\mathbf{2 0 1 3}$ & $\mathbf{2 0 1 4}$ & $\mathbf{2 0 1 3}$ & $\mathbf{2 0 1 4}$ \\
\hline Cultivars (C) & & & & & \\
Sakha93 & $47.39 \mathrm{a}$ & $47.88 \mathrm{a}$ & $50.43 \mathrm{a}$ & $51.22 \mathrm{a}$ & $334.56 \mathrm{a}$ & $337.34 \mathrm{a}$ \\
Gemmiza9 & $44.48 \mathrm{~b}$ & $44.86 \mathrm{~b}$ & $48.65 \mathrm{~b}$ & $48.82 \mathrm{~b}$ & $326.86 \mathrm{~b}$ & $329.64 \mathrm{~b}$ \\
\hline Salicylic acid levels (SA) $\left(\mathrm{mg} \mathrm{L}^{-1}\right)$ \\
\hline 0 & $43.24 \mathrm{c}$ & $44.56 \mathrm{c}$ & $48.25 \mathrm{c}$ & $48.38 \mathrm{c}$ & $325.22 \mathrm{c}$ & $328.65 \mathrm{c}$ \\
100 & $44.87 \mathrm{~b}$ & $45.44 \mathrm{~b}$ & $49.15 \mathrm{~b}$ & $49.85 \mathrm{~b}$ & $329.55 \mathrm{~b}$ & $332.37 \mathrm{~b}$ \\
200 & $46.24 \mathrm{a}$ & $46.94 \mathrm{a}$ & $49.85 \mathrm{a}$ & $50.19 \mathrm{a}$ & $332.45 \mathrm{a}$ & $335.94 \mathrm{a}$ \\
C $\times$ SA & $\mathrm{ns}$ & $\mathrm{ns}$ & $\mathrm{ns}$ & $\mathrm{ns}$ & $\mathrm{ns}$ & $\mathrm{ns}$ \\
\hline
\end{tabular}

Data within columns followed by different letters are significantly different at $\mathrm{P}<0.05$; ns, no significant difference.

Sakha 93 significantly recorded maximum 1000-grain weight (47.39 and $47.88 \mathrm{~g})$, number of grains spike ${ }^{-1}(50.43$ and 51.22$)$ and number of spikes $\mathrm{m}^{-2}$ (334.56 and 337.34), respectively as was found in both seasons (Table 4) as compared to Gemmiza 9 which recorded minimum 1000-grain weight (44.48 and $44.86 \mathrm{~g}$ ), number of grains spike ${ }^{-1}(48.65$ and 48.82$)$ and number of spikes $\mathrm{m}^{-2}$ (326.86 and 329.64) in both seasons, respectively (Table 4). It was noted from the results that Gemmiza 9 was hardly affected by salt stress whereas number of grains and spikes were more severely influenced in respect of high increase in unfilled grain number and decline in 1000-grain weight as compared to Sakha93. These results are in harmony with the findings of Maswada \& Abd El-Kader (2016). 
Exogenous application of salicylic acid appreciably increased 1000-grain weight, number of grains spike ${ }^{-1}$ and number of spikes $\mathrm{m}^{-2}$ in both seasons (Table 4). The highest 1000-grain weight (46.24 and $46.94 \mathrm{~g}$ ), number of grains spike ${ }^{-1}$ (49.85 and 50.19) and number of spikes $\mathrm{m}^{-2}$ (332.45 and 335.94) were recorded by exogenous application (200 $\mathrm{mg} \mathrm{L}^{-1} \mathrm{SA}$ ) respectively as was found in both seasons compared to control treatment (without application SA) which recorded the lowest 1000-grain weight (43.24 and $44.56 \mathrm{~g})$, number of grains spike ${ }^{-1}$ (48.25 and 48.38) and number of spikes $\mathrm{m}^{-2}$ (325.22 and 328.65) in both seasons, respectively. The reversal of the detrimental impacts of salt stress on yield-traits by exogenous salicylic acid application was observed in both sensitive and tolerant cultivars. The beneficial impacts of salicylic acid might be due to early application at vegetative growth leading to promotive impact on post-heading development Desoky \& Merwad (2015). Desoky \& Merwad (2015) who reported that number of grains, number of spikes and 1000-grain weight were positively correlated with exogenous application of salicylic acid.

Effect of treatments on grain yield, straw yield and harvest index

Sakha 93 significantly recorded maximum grain yield (6.88 and 7.15 ton ha $\left.{ }^{-1}\right)$, straw yield (10.43 and 10.87 ton $\mathrm{ha}^{-1}$ ) and harvest index (39.75 and 40.24\%), respectively as was found in both seasons (Table 5) compared with Gemmiza9 which recorded lesser grain yield (6.27 and 6.38 ton $\left.^{-1} \mathrm{ha}^{-1}\right)$, straw yield (9.82 and 9.92 ton $\mathrm{ha}^{-1}$ ) and harvest index (38.92 and 39.14\%) in both seasons (Table 5). Abdullah et al. (2001) reported that there were many reasons of damage in grain formation of wheat under salt-affected soil, including $\mathrm{Na}^{+} / \mathrm{K}^{+}$ratio in plant parts. The results proved that the decline in sink size was attributed to higher $\mathrm{Na}^{+}$ absorption and lower $\mathrm{K}^{+}$absorption into sink size which was most pronounced in the salt sensitive cultivar (Gemmiza9) as compared to the salt tolerant cultivar (Sakha93). Also it was observed that grain yield reduction was mainly attributed to decrease in number of grains, number of spikes, 1000-grain weight, these results might be due to the decline in fertilization through pollen viability deterioration under salt stress (Maswada \&Abd El-Kader, 2016). Abdullah et al. (2001) also reported that straw yield reduction was attributed to higher $\mathrm{Na}^{+}$accumulation and lower $\mathrm{K}^{+}$accumulation into young leaves at the late vegetative growth and the shoots, in addition inhibit translocation of assimilates from leaves to grains which was most pronounced in the salt sensitive cultivar (Gemmiza 9) as compared to the salt tolerant cultivar (Sakha 93).

It is noticeable that grain yield, straw yield and harvest index gradually increased significantly with the increase of salicylic acid levels in both seasons of study, accordingly (Amin et al., 2008). External supply of salicylic acid at 200 $\mathrm{mg} \mathrm{L}^{-1}$ tended to maximize grain yield (9 and $\left.10 \%\right)$, straw yield (5 and $4 \%$ ) and harvest index ( 3 and $4 \%$ ) in both seasons of study respectively, as an average of salicylic acid application versus without salicylic acid application (Table 5). Amin et al. (2008) reported that yield reduction owing to salt-affected soil might be ameliorated by exogenous application of salicylic acid through its effect on ion balance, nutrient uptake and antioxidant enzyme activities.

Egypt. J. Agron. 38, No.3 (2016) 
TABLE 5. Effect of cultivars and salicylic acid levels on (grain yield, straw yield and harvest index, respectively) in 2013/2014 and 2014/2015 seasons.

\begin{tabular}{|c|c|c|c|c|c|c|}
\hline \multirow{2}{*}{ Treatments } & \multicolumn{2}{|c|}{$\begin{array}{c}\text { Grain yield } \\
\left(\text { ton } \mathrm{ha}^{-1}\right)\end{array}$} & \multicolumn{2}{|c|}{$\begin{array}{l}\text { Straw yield } \\
\left(\text { ton } \text { ha }^{-1}\right)\end{array}$} & \multicolumn{2}{|c|}{$\begin{array}{c}\text { Harvest index } \\
(\%)\end{array}$} \\
\hline & 2013 & 2014 & 2013 & 2014 & 2013 & 2014 \\
\hline $\begin{array}{l}\text { Cultivars (C) } \\
\text { Sakha93 } \\
\text { Gemmiza9 }\end{array}$ & $\begin{array}{l}6.88 \mathrm{a} \\
6.27 \mathrm{~b}\end{array}$ & $\begin{array}{l}7.15 \mathrm{a} \\
6.38 \mathrm{~b}\end{array}$ & $\begin{array}{l}10.43 \mathrm{a} \\
9.82 \mathrm{~b}\end{array}$ & $\begin{array}{l}10.87 \mathrm{a} \\
9.92 \mathrm{~b}\end{array}$ & $\begin{array}{l}39.75 \mathrm{a} \\
38.92 \mathrm{~b}\end{array}$ & $\begin{array}{l}40.24 \mathrm{a} \\
39.14 \mathrm{~b}\end{array}$ \\
\hline \multicolumn{7}{|c|}{ Salicylic acid levels (SA) $\left(\mathrm{mg} \mathrm{L}^{-1}\right)$} \\
\hline $\begin{array}{l}0 \\
100 \\
200\end{array}$ & $\begin{array}{l}6.05 \mathrm{c} \\
6.45 \mathrm{~b} \\
6.64 \mathrm{a}\end{array}$ & $\begin{array}{l}6.23 \mathrm{c} \\
6.65 \mathrm{~b} \\
6.92 \mathrm{a}\end{array}$ & $\begin{array}{c}9.75 \mathrm{c} \\
10.07 \mathrm{~b} \\
10.22 \mathrm{a}\end{array}$ & $\begin{array}{c}9.87 \mathrm{c} \\
10.18 \mathrm{~b} \\
10.28 \mathrm{a}\end{array}$ & $\begin{array}{l}38.29 \mathrm{~b} \\
39.04 \mathrm{a} \\
39.38 \mathrm{a}\end{array}$ & $\begin{array}{l}38.70 \mathrm{c} \\
39.51 \mathrm{~b} \\
40.23 \mathrm{a}\end{array}$ \\
\hline $\mathrm{C} \times \mathrm{SA}$ & ns & ns & ns & ns & ns & $\mathrm{ns}$ \\
\hline
\end{tabular}

Data within columns followed by different letters are significantly different at $\mathrm{P}<0.05$; ns, no significant difference.

Effect of treatments on leaf $\mathrm{K}^{+}$, leaf $\mathrm{Na}^{+}$and leaf $\mathrm{K}^{+} / \mathrm{Na}^{+}$

Most of the physiological characters assessed showed a significantly differences between both cultivars. Under salt-affected soil, leaf $\mathrm{K}^{+} / \mathrm{Na}^{+}$was still the strongest determinant of salinity tolerance. Leaf $\mathrm{K}^{+}$content was significantly increased in Sakha93 as compared to Gemmiza9 in both seasons, On the contrary with leaf $\mathrm{Na}^{+}$content was significantly higher in Gemmiza9 as compared to Sakha 94 in both seasons under salt-affected soil (Table 6). Sakha93 significantly recorded maximum leaf $\mathrm{K}^{+}(6.85$ and $7.08 \mathrm{mg} / \mathrm{g}$ LDW) compared with Gemmiza9 which recorded minimum leaf $\mathrm{K}^{+}(6.05$ and $6.23 \mathrm{mg} / \mathrm{g} \mathrm{LDW})$, respectively in both seasons. However, Sakha93 significantly recorded minimum leaf $\mathrm{Na}^{+}(7.68$ and $7.72 \mathrm{mg} / \mathrm{g}$ LDW) compared with Gemmiza9 which recorded maximum leaf $\mathrm{Na}^{+}(8.74$ and $8.87 \mathrm{mg} / \mathrm{g}$ LDW) respectively in both seasons. While, Sakha93 significantly recorded maximumleaf $\mathrm{K}^{+} / \mathrm{Na}^{+}(0.89$ and 0.92 $\mathrm{mg} / \mathrm{g}$ LDW) respectively, as was found in both seasons (Table 6) as compared to Gemmiza 9 which recorded minimum leaf $\mathrm{K}^{+} / \mathrm{Na}^{+}(0.69$ and $0.71 \mathrm{mg} / \mathrm{g} \mathrm{LDW})$ in both seasons, respectively as shown in (Table 6). Sakha93 (salt-tolerant cultivar) accumulated larger $\mathrm{K}^{+}$concentrations and lower $\mathrm{Na}^{+}$concentrations in the leaves and higher $\mathrm{K}^{+} / \mathrm{Na}^{+}$ratio which maintains high chlorophyll content and osmotic regulation for more plant growth on the contrary with Gemmiza9 (salt-sensitive cultivar). Furthermore, supply assimilates from leaves to spikes during anthesis and grains during grain filling stage and lastly increases seed set. A negative effect has been observed between $\mathrm{Na}^{+}$concentration in floral parts and salt tolerance in terms of grain yield. The results of the current investigation are in full agreement with Rahnama et al. (2011) and Abu Hasan et al. (2015). 
TABLE 6. Effect of cultivars and salicylic acid levels on (leaf $\mathrm{K}^{+}$, leaf $\mathrm{Na}^{+}$and leaf $\mathrm{K}^{+} / \mathrm{Na}^{+}$, respectively) in $2013 / 2014$ and $2014 / 2015$ seasons.

\begin{tabular}{|l|c|c|c|c|c|c|}
\hline \multirow{2}{*}{ Treatments } & \multicolumn{2}{|c|}{$\begin{array}{c}\text { Leaf K } \\
(\mathbf{m g} / \mathbf{g} \text { LDW })\end{array}$} & \multicolumn{2}{c|}{$\begin{array}{c}\text { Leaf Na }^{+} \\
(\mathbf{m g} / \mathbf{g} \text { LDW })\end{array}$} & \multicolumn{2}{c|}{$\begin{array}{c}\text { Leaf K}^{+} / \mathrm{Na}^{+} \\
(\mathbf{m g} / \mathbf{g} \text { LDW })\end{array}$} \\
\cline { 2 - 7 } & $\mathbf{2 0 1 3}$ & $\mathbf{2 0 1 4}$ & $\mathbf{2 0 1 3}$ & $\mathbf{2 0 1 4}$ & $\mathbf{2 0 1 3}$ & $\mathbf{2 0 1 4}$ \\
\hline Cultivars (C) & & & & & & \\
Sakha93 & $6.85 \mathrm{a}$ & $7.08 \mathrm{a}$ & $7.68 \mathrm{~b}$ & $7.72 \mathrm{~b}$ & $0.89 \mathrm{a}$ & $0.92 \mathrm{a}$ \\
Gemmiza9 & $6.05 \mathrm{~b}$ & $6.23 \mathrm{~b}$ & $8.74 \mathrm{a}$ & $8.87 \mathrm{a}$ & $0.69 \mathrm{~b}$ & $0.71 \mathrm{~b}$ \\
\hline Salicylic acid levels (SA) $\left(\mathrm{mg} \mathrm{L}^{-1}\right)$ \\
\hline 0 & $6.22 \mathrm{c}$ & $6.46 \mathrm{c}$ & $8.68 \mathrm{a}$ & $8.95 \mathrm{a}$ & $0.72 \mathrm{c}$ & $0.72 \mathrm{c}$ \\
100 & $6.53 \mathrm{~b}$ & $6.78 \mathrm{~b}$ & $8.25 \mathrm{~b}$ & $8.07 \mathrm{~b}$ & $0.79 \mathrm{~b}$ & $0.84 \mathrm{~b}$ \\
200 & $6.95 \mathrm{a}$ & $7.14 \mathrm{a}$ & $7.85 \mathrm{c}$ & $7.66 \mathrm{c}$ & $0.88 \mathrm{a}$ & $0.93 \mathrm{a}$ \\
C $\times$ SA & $\mathrm{ns}$ & $\mathrm{ns}$ & $\mathrm{ns}$ & $\mathrm{ns}$ & $\mathrm{ns}$ & $\mathrm{ns}$ \\
\hline
\end{tabular}

Data within columns followed by different letters are significantly different at $\mathrm{P}<0.05$; ns, no significant difference.

A positive response from exogenous application of salicylic acid was recorded for both cultivars. Whereas exogenous application of salicylic acid tended to increase leaf $\mathrm{K}^{+}$content and decrease leaf $\mathrm{Na}^{+}$content under saltaffected soil in both seasons. Exogenous application of salicylic acid significantly increased leaf $\mathrm{K}^{+}$and leaf $\mathrm{K}^{+} / \mathrm{Na}^{+}$and decreased leaf $\mathrm{Na}$ in both seasons (Table 6). Application $200 \mathrm{mg} \mathrm{L}^{-1} \mathrm{SA}$ led to maximize leaf $\mathrm{K}^{+}$(6.95 and $7.15 \mathrm{mg} / \mathrm{g} \mathrm{LDW})$ and leaf $\mathrm{K}^{+} / \mathrm{Na}^{+}(0.88$ and $0.93 \mathrm{mg} / \mathrm{g} \mathrm{LDW})$ and minimize leaf $\mathrm{Na}^{+}(7.85$ and $7.66 \mathrm{mg} / \mathrm{g} \mathrm{LDW})$ respectively in both seasons (Table 6) as compared to control treatment (without application). In salt-affected soils, the reduction in growth traits and leaf chlorophyll might be due to higher $\mathrm{Na}^{+}$ content and lower $\mathrm{K}^{+}$content in the leaves and finally the yield reduction (Meneguzzo et al., 1999). These circumstances led to many restrictions such as ion imbalance, lower water absorption, high osmotic potential, restraint of biochemical processes and more reactive oxygen species. Salicylic acid application had a protective role under salt stress and could regulate of ion balance and transport (Amin et al., 2008). SA could alleviate of salt stress impacts and enhance water potential. The disturbance in stomatal conductance, transpiration rate and photosynthesis under salt stress could be reversed by external supply of salicylic acid which capable to prevent the destructive effect of ROS (Abu Hasan et al., 2015).

Effect of treatments on of antioxidant enzyme activities:

The results in Fig. 1 showed CAT and POX activities in the leaves of wheat under salt-affected soil in 2013/2014 and 2014/2015 winter seasons. In the current study, it was found from the data that the increase in salicylic acid level up to $200 \mathrm{mg} \mathrm{L}^{-1}$ resulted in more catalase and peroxidase activities in both seasons (Fig.1). The activities of CAT and POX were much higher in Sakha93 (tolerant cultivar) than Gemmiza9 (sensitive cultivar) in both seasons under saltaffected soil by exogenous application of $200 \mathrm{mg} \mathrm{SA} \mathrm{L}^{-1}$ (Fig.1).

Egypt. J. Agron. 38, No.3 (2016) 


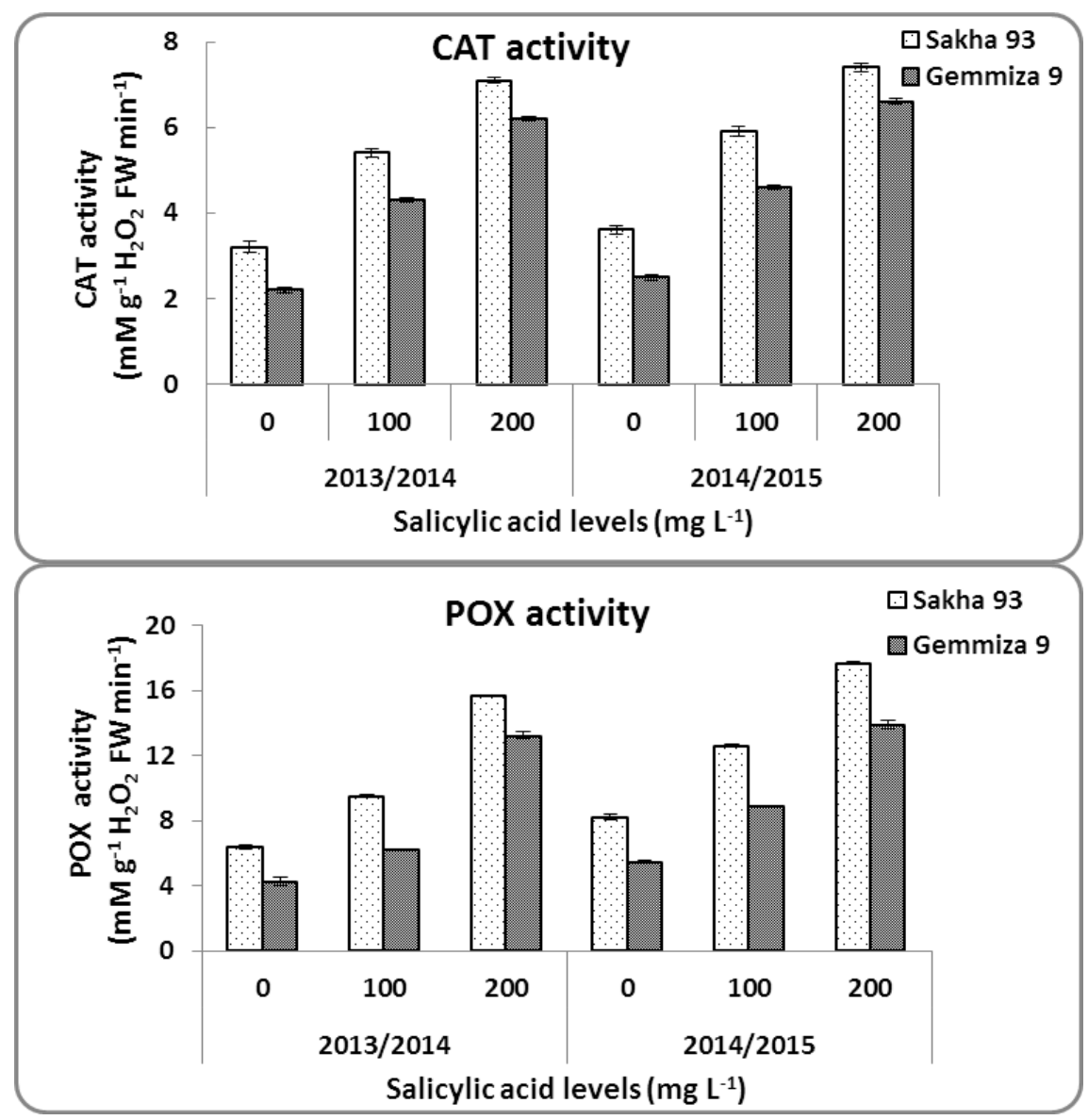

Fig.1. Effect of salicylic acid levels $\left(0,100\right.$ and $\left.200 \mathrm{mg} \mathrm{SA} \mathrm{L}^{-1}\right)$ on antioxidant enzymes activities (CAT and POX) of two wheat cultivars in 2013/2014 and 2014/2015 seasons. Data are the mean \pm SE of three replicates.

These higher levels of antioxidant enzymes could be regarded to ability of antioxidant enzymes to promote salinity tolerance against oxidative deterioration. Exogenous application of salicylic acid had increased antioxidant enzyme activities in wheat plants, which could maintain growth traits, metabolic processes, oxidative stress resistance, osmotic balance and increase the stability of membranes and $\mathrm{CO}_{2}$ fixation in salt-affected soil (Meneguzzo et al., 1999 and Maswada \& Abd El-Kader, 2016). Hence the increase in activities of antioxidant enzymes of wheat plants owing to salicylic acid application had a crucial role in scavenging of ROS and closely related with reduction of oxidative deterioration (Hafez \& Hafez, 2016).

Acknowledgements:The author is grateful to the Water Management Research Institute, for support of this research. Moreover, the author would like to express 
a special thanks to Dr Waleed Abou El-Hassan (Head of Farm Irrigation Management Department) for his help in this study. The author is also appreciated of Plant Pathology and Biotechnology Laboratory, Dept. of Agric. Botany, Fac. of Agric., Kafrelsheikh University, Egypt.

\section{References}

Abdullah, Z., Khan, M.A. and Flowers, T.J. (2001) Causes of sterility in seed set of rice under salinity stress. J. Agro. Crop Sci. 187, 25-32.

Abu-Hasan, H. R. H., Nurealam, S., Khatun, M., Rabiul, I. and Abdullah, M. (2015) Evaluation of wheat genotypes for salt tolerance based on some physiological traits. $J$. Crop Sci. Biotech. 18 (5), 333-340.

Aebi, H. (1984) Catalase in vitro. Methods Enzymol. 105, 121-126.

Amin, A.A., Rashad, El-Sh. and Fatma, M. (2008) Changes in morphological, physiological and reproductive characters of wheat plants as affected by foliar application with salicylic acid and ascorbic acid. Aust. J. Basic. Appl. Sci. 2,252-261.

Amjad, M., Akhtar, J., Haq, M. A., Riaz, M.A. and Jacobsen, S.E. (2014) Understanding salt tolerance mechanism in wheat genotypes by exploring antioxidant enzymes activity. Pak. J.Agric. Sci. 51, 1-8.

Arfan, M., Athar, H. R. and Ashraf, M. (2007) "Does exogenous application of salicylic acid through the rooting medium modulate growth and photosynthetic capacity in two differently adapted spring wheat cultivars under salt stress?" J. Plant Physiol. 164 (6), 685-694.

Desoky, S.M. and Merwad, A. M. (2015) Improving the salinity tolerance in wheat plants using salicylic and ascorbic acids. J. Agric. Sci. 7(10), 203-217.

Duncan, B.D. (1955) Multiple ranges and multiple F-test. Biometri.11, 1-42.

El-Lethy, S.R., Abdelhamid, M.T. and Reda, F. (2013) Effect of potassium application on wheat (Triticum aestivum L.) cultivars grown under salinity stress. World Appl. Sci. J. 26, 840-850.

FAO (2014) FAO land and plant nutrition management service http:www.fao.org/ag/agl/agll/spush [Last accessed 25 April2014].

Ghassemi, F., Jakeman, A.J. and Nix, H.A. (1995) "Salinization of Land and Water Resources". University of New South Wales Press Ltd., Canberra, Australia, pp. 562.

Gomez, K.A. and Gomez, A.A. (1984) "Statistical Procedures for Agricultural Research". John Wiley and Sons, $2^{\text {nd }}$ ed. pp.180, New Yourk, U.S.A.

Gonzalez, L. and Gonzalez - Vilar, M. (2001) Determination of relative water content. In: "Handbook of Plant Ecophysiology Techniques" Reigosa, M. J.(Ed.). pp. 207-212, Dordrecht: Kluwer Academic,.

Egypt. J. Agron. 38, No.3 (2016) 
Hafez, E.M. and Abdelaal, Kh.A.A. (2015) Impact of nitrogen fertilization levels on morphophysiological characters and yield quality of some maize hybrids (Zea mays L.). Egypt. J. Agron. 37 (1), 35-48.

Hafez, E.M. and Abou El-Hassan, W.H. (2015) Nitrogen and water utilization efficiency of barley subjected to desiccated conditions in moderately salt-affected soil. Egypt. J. Agron. 37(2), 231 -249.

Hafez, E.M. and Gharib, H.S. (2016) Effect of exogenous application of ascorbic acid on physiological and biochemical characteristics of wheat under water stress. Int. J. Plant Prod. 10(4), 579-596.

Hafez, E.M. and Hafez, Y. M. (2016) Pivotal influence of chemical inducers on antioxidant enzyme activities and barley yield under biotic and abiotic stresses. Egypt. J. Agron. 38(2), 209-224.

Hafez, E.M. and Kobata, T. (2012) The effect of different nitrogen sources from urea and ammonium sulfate on the spikelet number in Egyptian spring wheat cultivars on well watered pot soils. Plant Prod. Sci. 15(4), 332-338.

Hafez, E.M, Abou El-Hassan, W.H., Gaafar, I.A. and Seleiman, M.F. (2015) Effect of gypsum application and irrigation intervals on clay saline-sodic soil characterization, rice water use efficiency, growth, and yield. J. Agric. Sci. 7 (12), 208-219.

Hafez, E.M., Ragab, A.Y. and Kobata, T. (2014) Water-use efficiency and ammonium$\mathrm{N}$ source applied of wheat under irrigated and desiccated conditions. Int. J. Plant Soil Sci. 3(10), 1302-1316.

Hafez, Y. M., Bacsó, R., Király, Z., Künstler, A. and Király, L. (2012) Up-regulation of antioxidants in tobacco by low concentrations of $\mathrm{H}_{2} \mathrm{O}_{2}$ suppresses necrotic disease symptoms. Phytopathol. 102, 848-856.

Hammerschmidt, R., Nuckles, E. M. and Kuć, J. (1982) Association of enhanced peroxidase activity with induced systemic resistance of cucumber to Colletotrichum lagenarium. Physiol. Plant Pathol. 20 (1),73-82.

Jeon, M. W., Ali, M. B., Hahn, E. J. and Paek, K. Y. (2006) Photosynthetic pigments, morphology and leaf gas exchange during ex vitro acclimatization of micropropagated CAM Doritaenopsis plantlets under relative humidity and air temperature. Environ. Exp. Bot. 55,183-194.

Manzoor, K., Noshin, I., Nazima, B., Bashir, A. and Muhammad, A. (2015) Effect of salicylic acid on the growth and physiological characteristics of maize under stress conditions. J. Chem. Soc. Pak. 37(3), 588-593.

Markwell, J., Osterman, J.C. and Mitchell, J.L. (1995) Calibration of the Minolta SPAD-502 leaf chlorophyll meter. Photosynth Res. 46, 467-472.

Maswada H.F. and Abd El-Kader, N.I.K. (2016) Redox halopriming: A promising strategy for inducing salt tolerance in bread wheat. J. Agro Crop Sci. 202, 37-50. 
Meneguzzo, S., Navarri-Izzo, F. and Izzo, R. (1999) Antioxidative responses of shoot and root of wheat to increasing $\mathrm{NaCl}$ concentrations. J. Plant Physiol. 155, 274-80.

Munns, R. and Tester, M. (2008) Mechanisms of salinity tolerance. Annu. Rev. Plant Biol. 59, 651-681.

Rahnama, A., Poustini, K., Tavakkol-Afshari, R., Tavakkol-Afshari, Ahmadi, A. and Alizadeh, H. (2011) Growth properties and ion distribution in different tissues of bread wheat genotypes (Triticum aestivum L.) differing in salt tolerance. J. Agro. Crop Sci. 197, 21-30.

Rana, V., Ram, S., Nehra, K. and Sharma, I. (2015) Differential expression analysis of salt stress related genes TaSRG and TaRUB1 in wheat genotypes. J. Wheat Res. 7, 71-73.

Sakhabutdinova, A. R., Fatkhutdinova, D. R., Bezrukova, M. V. and Shakirova, F. M. (2003) Salicylic acid prevents the damaging action of stress factors on wheat plants. In: Proceedings of the European Workshop on Environmental Stress and Sustainable Agriculture, 7-12 September 2002, Varna, Bulgaria, pp.314-319.

Shabala, S. and Munns, R. (2012) Salinity stress: physiological constraints and adaptive mechanisms. In: "Plant Stress Physiology" S. Shabala, (Ed.). pp. 59-93, CABI Publishing, Wallingford, UK.

Shakirova, F.M. A.R., Sakhabutdinova, M.V., Bezrukova, R.A. and Fatkhutdinova, D. R. (2003) "Changes in the hormonal status of wheat seedlings induced by salicylic acid and salinity, Plant Science, 164 (3), 317-322.

Singh, A., Bhushan B., Gaikwad, K., Yadav, O.P., Kumar, S. and Rai, R.D. (2015) Induced defence response of contrasting bread wheat genotypes under differential salt stress imposition. Indian J. Biochem. Biophys. 52, 75-85.

Temminghoff, E.E.J.M. and Houba,V.J.G. (2004) "Plant Analysis Procedures", $2^{\text {nd }}$ ed. Kluwer Academic Publishers, Dordrecht, Netherlands.

Zhang, J. L., Flowers, T. J. and Wang, S. M. (2010) Mechanisms of sodium uptake by roots of higher plants. Plant Soil. 326, 45-60.

Zhu, M., Shabala, S., Shabala, L., Fan, Y. and Zhou, M. X. (2016) Evaluating predictive values of various physiological indices for salinity stress tolerance in wheat. J. Agro. Crop. Sci. 202,115-124.

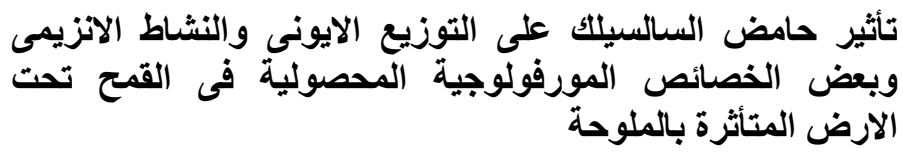

Egypt. J. Agron. 38, No.3 (2016) 
أجريت تجربة حقلية لدراسة تأثثرات ملوحة التربة على الصفات المورفولوجية

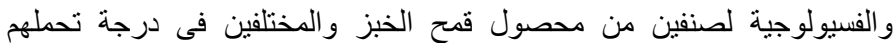

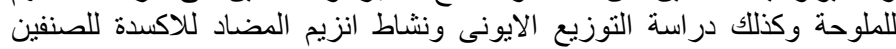

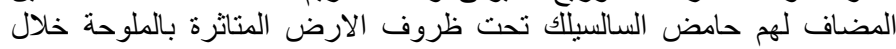

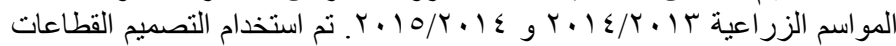

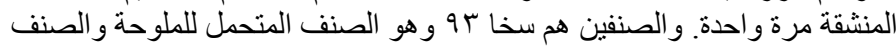

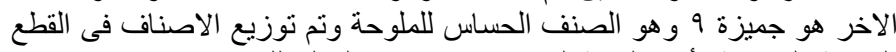

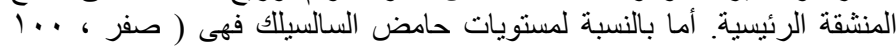

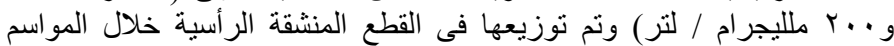

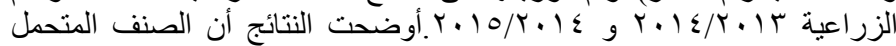

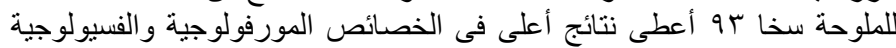

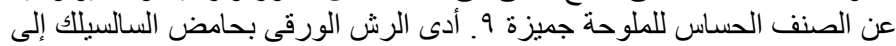

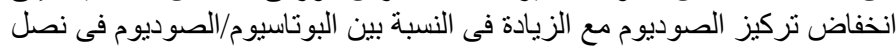

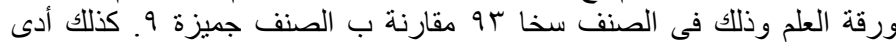

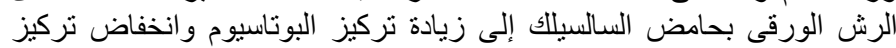

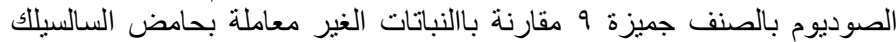

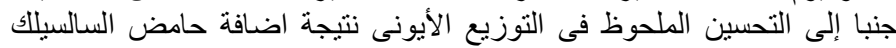

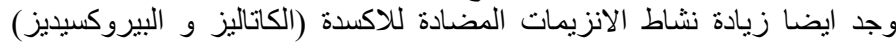

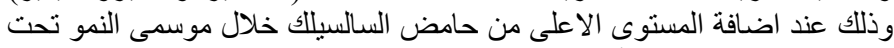

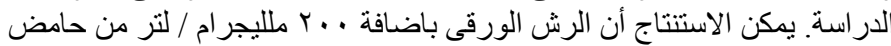

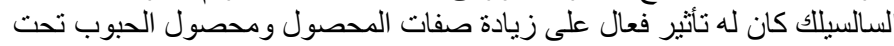

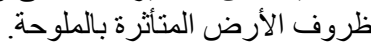

